\title{
PEMAKAIAN BAHASA INDONESIA YANG BAIK DAN BENAR DALAM PENYELESAIAN KASUS PERSIDANGAN PERDATA
}

\author{
Putri Sarah ${ }^{1}$, Hindun ${ }^{2}$ \\ putrisarah316@gmail.com ${ }^{1}$, hindun@uinjkt.ac.id ${ }^{2}$ \\ Universitas Pembangunan Nasional "Veteran" Jakarta ${ }^{1}$,Universitas Islam Negeri Syarif Hidayatullah ${ }^{2}$
}

\begin{abstract}
Abstrak-- Masih banyak orang yang terkesan terjebak saat mereka berhadapan dengan hukum hanya karena penggunaan bahasa Indonesia yang belum tepat. Hal ini dapat ditemui dalam sebuah penyelesaian kasus persidangan perdata. Pada penyelesaian perkara perdata sering ditemui pada istilah yang hanya diketahui oleh lembaga peradilan. Misalnya pada kata paten atau penggunaan bahasa asing seperti force majeure dan seiendes-sollen yang membuat orang awam sulit mengerti arti kata tersebut sehingga mengkibatkan maksud lain dari arti yang sebenarnya. Tujuan penelitian ini adalah untuk menginventarisasi dan mendeskripsikan karakteristik bahasa yang baik dan benar dalam bidang hukum yang digunakan dalam penyelesaian kasus persidangan perdata serta pengaruhnya terhadap dunia hukum. Penelitian ini menggunakan metode pendekatan campuran, yaitu menggabungkan metode kualitatif dan kuantitatif, dengan teknik penyebaran angket dan studi pustaka. Hasil penelitian ini menunjukkan beberapa ciri khas penggunaan tuturan bahasa hukum, struktur bahasa indonesia yang baik dan benar,dan pengaruh dari penggunaan bahasa hukum terhadap hasil penyelesaian perkara. Karakteristik tersebut diantaranya : pertama, penggunaan istilah asing oleh para praktisi hukum. Kedua, penerapan penggunaan bahasa indonesia yang baik dan benar yang perlu diterapkan oleh semua rakyat indonesia. Sehingga kelak akhirnya , suatu perkara dapat diselesaikan dengan menciptakan keadilan bagi semua pihak
\end{abstract}

Kata Kunci : Bahasa Indonesia, Hukum,Mediasi,Perdata

\section{GOOD AND CORRECT USE OF INDONESIAN LANGUAGE IN CIVIL TRIAL CASE SETTLEMENT}

\begin{abstract}
There are still many people who seem trapped when they are dealing with the law just because the use of Indonesian language is not right. This can be found in the settlement of a civil court case. In the settlement of civil cases, it is often found in terms that are only known by the judiciary. For example, the word patent or the use of foreign languages such as force majeure and seiendes-sollen which makes it difficult for ordinary people to understand the meaning of the word so that it results in another meaning from the actual meaning. The purpose of this study is to inventory and describe the characteristics of good and correct language in the legal field used in the settlement of civil court cases and their influence on the legal world. This study uses a mixed method approach, which combines qualitative and quantitative methods, with questionnaires and literature studies. The results of this study indicate several characteristics of the use of legal language speech, the structure of a good and correct Indonesian language, and the influence of the use of legal language on the outcome of case settlement. These characteristics include: first, the use of foreign terms by legal practitioners. Second, the application of good and correct use of Indonesian that needs to be applied by all Indonesian people. So that in the end, a case can be resolved by creating justice for all parties
\end{abstract}

Key Words: Indonesian, Law, Mediation, Civil

Article Submitted: 01-07-2021 Article Accepted: 28-07-2021 Article Published: 21-08-2021

Corresponden Author: Putri Sarah E-mail: putrisarah316@gmail.com

DOI: http://dx.doi.org/10.31851/pembahsi.v11i2.6727 


\section{PENDAHULUAN}

Mediasi merupakan bentuk alternatif penyelesaian perkara yang telah tumbuh dan berkembang sejalan dengan tumbuhnya keinginan manusia menyelesaikan sengketa secara cepat dan memuaskan kedua belah pihak (Anisa, 2015). Dalam hal ini dimaksudkan bahwa mediasi ialah salah satu metode untuk menyelesaikan masalah atau persengketaan di pengadilan. Untuk menciptakan tujuan hukum tersebut , maka diperlukan juga bahasa Indonesia yang baik dan benar, yang nantinya berdampak pada penyelesaian kasus pada persidangan. Sehingga tidak ada lagi pihak yang merasa diberatkan oleh keputusan para lembaga pengadilan.

Penulisan ini dibatasi pada kata kata yang digunakan oleh jaksa dan pengacara serta kata- kata serapan ataupun istilah -istilah dalam sebuah penyelesaian kasus persidangan perdata. Penelitian ini penulis lakukan karena beberapa alasan. Pertama, penelitian ini sudah dilakukan sebelumnya namun cakupannya sempit, sehingga ini membuat penulis tertarik untuk mengulas lebih dalam yang nantinya akan menambah wawasan dan pengetahuan para pembaca tentang bahasa yang baik

dan benar dalam muka hukum. Kedua, penting untuk kita sebagai negara hukum untuk mengetahui berbagai istilah hukum tanpa terkecuali, karena kita sebagai warga negara yang baik adalah warga yang mengerti dan taat pada hukum yang berlaku. Ketiga, penulis sebagai mahasiswa hukum tentu perlu menambah wawasan mengenai bahasa indonesia yang baik dan benar dalam penyelesaian kasus persidangan perdata, karena hal ini lah yang dapat penulis gunakan untuk dunia pekerjaan kedepannya dan dengan dilakukannya penelitian inilah penulis dapat mengembangkan pemikirannya bukan hanya untuk diri sendiri namun untuk semua pembaca.

Pemakaian bahasa indonesia dikatakan dengan baik dan benar (Endang \& Fitriani, 2019), apabila tuturan sudah sesuai dengan kriteria. Kriteria yang dimaksud adalah tuturan baik lisan maupun tulis, telah sesuai dengan kaidah yang berlaku dan sesuai dengan situasi kebahasaan yang dihadapi. Kriteria pemakaian bahasa indonesia dikatakan dengan benar jika telah sesuai dengan kaidah yang berlaku. Kaidah bahasa yang harus diperhatikan oleh para pemakai mencakupi lima aspek, yaitu (1) tata 
bunyi (fonologi), (2) tata bahasa (kata dan kalimat), (3) kosa kata (termasuk istilah), (4) ejaan, dan (5) makna(Muaffaq, 2012).

Berbahasa indonesia dengan baik dan benar, terkait dengan dua hal, yaitu sesuai dengan kaidah dan sesuai dengan situasi pemakaian bahasa. Berbahasa Indonesia dengan benar terkait dengan taat kaidah. Kaidah bahasa Indonesia dapat dilihat pada Pedoman Umum Ejaan Bahasa Indonesia yang Disempurnakan (PUEBID).Pedoman ini sebenarnya sudah diresmikan penggunaannya mulai tanggal 16 Agustus 1972. (Mustakim, 1996) .

\section{METODE}

Disituasi pandemi seperti ini, mengharuskan kita semua untuk berada dirumah. Hal ini karena tetap di rumah saja merupakan salah satu cara memutus mata rantai penyebaran covid -19 . Oleh karena itu sebagai penulis, hal ini menjadi salah satu hambatan dalam pembuatan karya tulis ilmiah. Terkait judul yang penulis ambil mengenai “

PEMAKAIAN BAHASA INDONESIA YANG BAIK DAN BENAR DALAM PENYELESAIAN KASUS

PERSIDANGAN PERDATA”. maka lokasi dan waktu penelitian yang penulis lakukan adalah penyebaran angekt diruang lingkup mahasiswa hukum tahun 2021 dibeberapa perguruan tinggi dengan kurung waktu 2 hari yaitu pada taggal 15 dan 16 November.

Pada penelitian ini, penulis memilih untuk menggunakan metode penelitian dengan pendekatan campuran. Penelitian campuran atau yang dikenal denga mix methods adalah penelitian yang mencakup kedua pendekatan yaitu kualitatif dan kauntitatif dengan teknik penyebaran angket sebagai data kuantitatif dan studi pustaka sebagai data kualitatif. Sehingga penelitian ini deskriptif dan cenderung menggunakan analisis yang dilengkapi dengan data hasil angket yang berupa tabel dan diagram.

Namun proses dan makna lebih ditonjolkan dalam penelitian kualitatif yaitu mengenai arti dan kesimpulan dari data tabel dan diagram. Data dalam penelitian ini terdiri dari data utama atau data primer dan data kedua atau data skunder. Data utama dalam penelitian ini adalah kuesioner atau angket. Sedangkan data kedua atau data skunder adalah data yang peneliti dapatkan dari informan lain hanya untuk memperkaya data yang 
peneliti peroleh dari data utama. Misalnya adalah buku, majalah, koran ataupun jurnal yang beredar di berbagai situs terpercaya.

Analisis data merupakan proses kegiatan pengolahan hasil penelitian, yang dimulai dari menyusun, mengelompokkan, menelaah, dan menafsirkan data dalam serta hubungan antar konsep dan merumuskannya dalam hubungan antara unsur- unsur lain agar mudah dimengerti dan dipahami. Data yang sudah terkumpul kemudian dianalisis dengan reduksi data atau rangkuman hasil kuesioner, penyajian data dan penarikan kesimpulan dan verifikasi. Hal tersebut saling berhubungan dan berlangsung terus menerus selama penelitian dilakukan.

Jadi analisis data yang dilakukan adalah kegiatan yang dilakukan oleh peneliti dari awal sampai akhir penelitian.

\section{HASIL DAN PEMBAHASAN}

\section{Hasil Penelitian}

Setelah dilakukan penelitian dan analisis kuesioner yang telah dibagikan dan diisi oleh responden yang telah ditetapkan yaitu mahasiwa program studi hukum, maka peneliti menyimpulkan bahwa :
1. Dari diagram di bawah, dapat dilihat bahwa sebanyak $92,3 \quad \%$ dari responden sudah mengetahui bahasa indonesia yang baik dan benar. Sementara 7,7 \% dari responden belum mengetahui bahasa indonesia yang baik dan benar. Hal ini membuktikan bahasa indonesia sudah dipelajari dan dipahami dengan baik dan benar secara dominan.

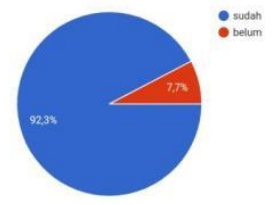

sumber : dokumen pribadi, 2021

2. Dari diagram di bawah, dapat dilihat bahwa sebanyak $61,5 \%$ dari responden sudah mengetahui karakteristik penggunaan bahasa indonesia yang baik dan benar. Sementara 38,5 \% dari responden belum mengetahui karakteristik penggunaan bahasa indonesia yang baik dan benar. Hal ini membuktikan responden dapat membuktikan karakteristik penggunaan bahasa indonesia yang baik dan benar secara lebih dominan.

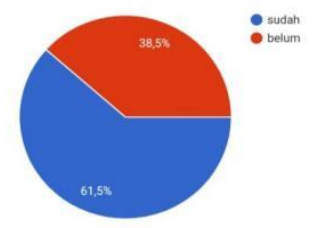


sumber : dokumen pribadi, 2021

3. Dari diagram dibawah, dapat dilihat bahwa kebanyakan responden belum mengetahui penjelasan mengenai bahasa hukum. Hal ini dibuktikan dengan sebanyak 38,5\% dari responden sudah mengetahui bahasa hukum. Sementaraa $61,5 \%$ dari responden belum mengetahui bahasa hukum.

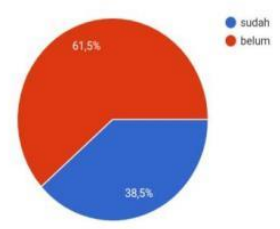

sumber : dokumen pribadi, 2021

4. Dari diagram di bawah, dapat disimpulkan masih banyak yang menganggap bahwa bahasa hukum di indonesia belum sesuai dengan kaidah kebahasaan. Hal ini dibuktikan dengan hanya $15,4 \%$ dari responden yang berpendapat bahwa bahasa hukum di indonesia sudah sesuai degan kaidah kebahasaan. Sementara 84,6 \% dari reaponden memilih bahasa hukum di indonesia belum sesuai dengan kaidah kebahasaan.



sumber : dokumen pribadi, 2021

5.Dari diagram di bawah, dapat dilihat hanya $15,4 \%$ dari responden yang sudah

mengetahui persamaan bahasa indonesia dengan bahasa hukum. Sementara 84,6\% dari responden merasa belum mengetahui persamaan bahasa indonesia dengan bahasa hukum.



sumber :

dokumen pribadi, 2021

6.Dari diagram di bawah, dapat dilihat hanya $30,8 \%$ dari responden yang sudah mengetahui perbedaan bahasa indonesia dengan bahasa hukum. Sementara 69,2 $\%$ dari responden merasa belum mengetahui perbedaan bahasa indonesia dengan bahasa hukum.

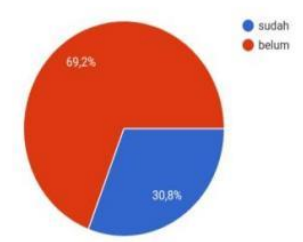

sumber : dokumen pribadi, 2021

7. Dari diagram dibawah, dapat dilihat bahwa menurut responden penggunaan bahasa indonesia dalam penyelesaian persidangan di indonesia belum baik dan benar. Hal ini dibuktikan dengan 69,2\% dari responden merasa penggunaan bahasa indonesia dalam penyelesaian persidangan di indonesia belum baik dan benar. Sementara hanya $30,8 \%$ dari 
responden yang merasa penggunaan bahasa indonesia dalam penyelesaian persidangan di indonesia sudah baik dan benar.

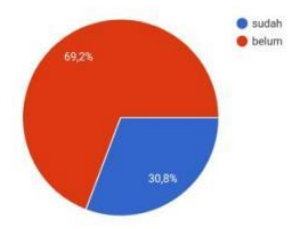

sumber : dokumen pribadi, 2021

8. Berdasarkan diagram dibawah, dapat dilihat bahwa hanya $38,5 \%$ dari responden yang sudah pernah membaca dokumen penyelesaian kasus. Sementara $61,5 \%$ dari responden belum pernah membaca dokumen penyelesaian kasus.

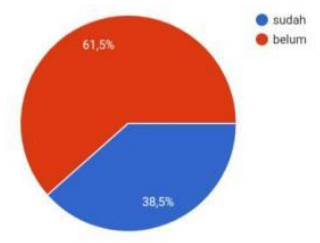

sumber : dokumen pribadi, 2021

9. Berdasarkan diagram dibawah, dapat dibuktikan bahwa responden lebih dominan belum pernah mendatangi sebuah persidangan. Hal ini dapat dibuktikan dengan hanya 23,1 \% dari responden yang sudah pernah mendatangi sebuah persidangan. Sementara 76,9\% dari responden belu m pernah mendatangi sebuah persidangan.

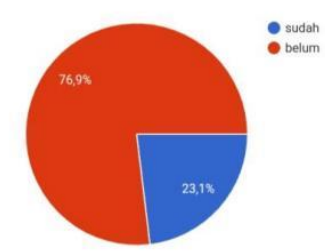

sumber : dokumen pribadi, 2021

10. Dari diagram di bawah, dapat dibuktikan bahwa sebagian besar responden belum mengetahui penulisan bahasa indonesia yang baik dan benar dalam penyelesaian kasus persidangan perdata yaitu 92,3\% dari responden belum mengetahui sementara hanya $7,7 \%$ lainnya dari responden sudah megetahui penulisan bahasa indonesia yang baik dan benar dalam penyelesaian kasus persidangan perdata.

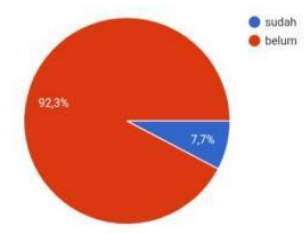

sumber : dokumen pribadi, 2021

11. Sama halnya dengan perdata. Dari diagram di bawah, dapat dibuktikan bahwa sebagian besar responden belum mengetahui penulisan bahasa indonesia yang baik dan benar dalam penyelesaian kasus persidangan pidana yaitu 92,3\% dari responden belum mengetahui sementara hanya 7,7 \% lainnya dari responden sudah megetahui penulisan bahasa indonesia yang baik dan benar 
dalam penyelesaian kasus persidangan pidana.

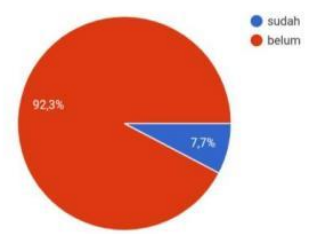

sumber : dokumen pribadi, 2021

\section{Pembahasan}

a. Karakteristik bahasa indonesia yang baik dan benar

Dengan gambaran kondisi tersebut, dimana pengetahuan masyarakat masih kurang tepat dan terbatas berkaitan dengan penggunaan bahasa indonesia yang baik dan benar dalam kehidupan sehari-hari. Maka,diperlukan pemahaman dan pengetahuan lebih terkait penggunaan bahasa indonesia yang baik dan benar. Berbahasa indonesia yang baik adalah berbahasa indonesia yang sesuai dengan tempat tempat terjadinya konteks berbahasa ,sesuai dengan siapa lawan bicara, dan sesuai dengan topik pembicaraannya. Bahasa indonesia yang baik tidak selalu harus baku,yang perlu diperhatikan dalam berbahasa indonesia yang baik adalah pemanfaatan ragam yang tepat dan serasi menurut golongan, penutur dan jenis pemakaian bahasa itulah. Karena pada dasarnya bahasa yang harus mengenai sasarannya tidak selalu perlu beragam baik. Alwi et al., (2003)PUEBI merupakan salah satu acuan dasar dari penggunaan bahasa Indonesia yang baik dan benar. Dalam PUEBI, telah diatur beberapa ketentuan mengenai pemakaian huruf, penulisan kata, pemakaian tanda baca, dan penulisan unsur serapan. Acuan penggunaan bahasa Indonesia yang benar tidak hanya berdasarkan PUEBI. Penggunaan bahasa Indonesia yang benar dapat mengacu pula pada Tata Bahasa Baku Bahasa Indonesia,Kamus Besar Bahasa Indonesia, dan Pedoman Umum Pembentukan Istilah.

b. Bahasa indonesia yang baik dan benar dalam persidangan perdata

Bahasa hukum mempunyai ciri-ciri yang tegas yang berfungsi sebagai pembeda yaitu mencakup konsep bahasa itu sendiri atau disebut dengan istilah. Istilah dalam konteks ini ,memiliki arti kata atau gabungan kata yang dengan cermat mengungkapkan makna konsep, proses, keadaan, atau sifat yang khas dalam bidang tertentu atau ungkapan khusus. Istilah ini terdapat dalam berbagai bidang ilmu pengetahuan 
(termasuk ilmu hukum) dan teknologi yang berkembang secara dinamis.

Dalam bidang ilmu hukum terdapat istilah kata hukum yang dirasa keliru penggunaannya sehingga kurang tepat apabila ditelisik lebih dalam. Kekeliruan tersebut tidak hanya terjadi di kalangan masyarakat awam, tetapi terjadi juga di masyarakat jurnalistik atau lembangan peradilan seperti hakim, jaksa, pengacara, atau pihak kepolisian sekalipun. Adapun contoh kata atau istilah yang penerapan nya salah atau bermakna ganda antara lain adalah :

- Paten

Kata paten, berasal dari bahasa inggris patent, yang awalnya berasal dari kata patere yang berarti membuka diri (untuk pemeriksaan publik), dan juga berasal dari istilah letters patent, yaitu surat keputusan yang dikeluarkan kerajaan yang memberikan hak eksklusif kepada individu dan pelaku bisnis tertentu. maksud istilah kata "mematenkan merek" adalah mendaftarkan merek, sedangkan istilah kata "Obat Paten" adalah obat yang manjur atau mujarab, bukan resep obat yang masih dalam perlindungan hak paten. Oleh karena itu, masyarakat harus tahu bahwa merek dan paten, merupakan dua istilah yang berbeda dan keduanya merupakan bagian dari kekayaan intelektual.

\section{- Gratifikasi}

Apabila merujuk pada kamus bahasa Inggris, nampaknya sudah terjadi kekeliruan dalam penggunaan istilah 'gratifikasi' yang merupakan kata terjemahan dari Bahasa inggris : "gratification". Definisi dari Collins English Dictionary - Complete \& Unabridged 2012 Digital Edition, yaitu "gratification" is :

1. pleasure, especially when gained from the satisfaction of a desire (kenikmatan, khususnya kepuasan yang didapat karena terpenuhinya keinginan)

2. something that gratifies (sesuatu yang memuaskan)

3. an obsolete word for 'gratuity' (kata usang yang bermakna 'hadiah' atau 'ganjaran').

Dari definisi di atas, gratifikasi tidak dipakai untuk merujuk kepada 'uang sogok atau uang suap'. Seperti terlihat pada definisi istilah 'gratuity' lebih sesuai dipakai ketimbang istilah 'gratification'. Namun, kata 'gratuitas' 
menyiratkan 'uang sebagai tanda terima kasih yang tulus', bukan 'uang tanda terima kasih yang mempunyai pamrih terselubung'(Kusno, 2011).

- Deponering

Deponering berasal dari Bahasa Belanda. Deponering bentuk kata benda dari deponeren, menurut definisi dalam bahasa aslinya di Negeri Belanda artinya menyerahkan, melaporkan, mendaftarkan. Ini bisa ditemukan dalam hukum dagang, administrasi maupun perpajakan. Contoh kalimat : Het bedrijf wilde zijn merknaam deponeren (Perusahaan itu ingin mendaftarkan nama mereknya). atau Gedeponeerde merk $=$ merek terdaftar. Proses penyerahan, pelaporan atau pendaftarannya

disebut deponering. Deponeren

jaarstukken atau laporan tahunan. (Placebo,Sahatsigiro.Mana yang Benar deponering atau deponeren jaarstukken. 2018)

c. Pengaruh bahasa indonesia yang baik dan benar terhadap kepastian hukum

berdasarkan hasil literatur bacaan , secara umum dapat disimpulkan bahwa bahasa indonesia yang baik dan benar memiliki hubungan dengan kepastian hukum, sedangakn secara khusus dapat disimpulkan pengistilahan, pengalimatan dan penulisan di dalam bahasa hukum yang yang sesuai dengan kaidah bahasa indonesia yang baik dan benar lebih mudah dipahami makna atau konsep yang terkandung di dalamnya.

Oleh sebab itu, rumusan norma hukum yang ada dapat menciptakan kepastian hukum. Selain itu, dapat disimpulkan norma rumusan bahasa Indonesia hukum yang mampu menciptakan kepastian hukum secara garis besar dapat dikelompokkan menjadi tiga, yaitu norma rumusan pengistilahan, pengalimatan, dan penulisan bahasa Indonesia hukum (BIH). Norma rumusan pengistilahan $\mathrm{BIH}$ yang mampu menciptakan kepastian hukum adalah pengistilahan yang tidak rancu, penempatannya di dalam kalimat benar, cermat, tepat, lazim, dan serasi, dan memiliki tautan dengan istilah hukum lainnya. Norma rumusan pengalimatan BIH yang mampu menciptakan kepastian hukum adalah pengalimatan yang memiliki kesejajaran bentuk (paralel), ketepatan dalam menempatkan fungsifungsi kalimat, kesatuan pikiran (unity), dan kelogisan. Selanjutnya, norma rumusan penulisan $\mathrm{BIH}$ yang mampu 
menciptakan kepastian hukum adalah penulisan yang menggunakan huruf yang tepat, tanda baca yang tepat dan ajeg, dan mengikuti konvensi atau kesepakatan yang terdapat di dalam bidang hukum. (inal,Mohamad, bahasa indonesia hukum dalam perspektif kepastian hukum. 2013)

d. Upaya untuk meminimalisir dampak dari penggunaan bahasa indonesia yang belum baik dan benar terhadap penyelesaian kasus persidangan perdata

Berkaitan dengan proses komunikasi antara mediator dengan dua pihak yang bersengketa, faktor penggunaan jenis tuturan dan strategi penyampaian sangatlah penting untuk diperhatikan. Selain itu, mediator harus memahami kondisi dan situasi yang dialami oleh klien sehingga dapat memilih tuturan yang sesuai. Kesesuaian tuturan ini berpengaruh pada keputusan pihak bersengketa selanjutnya.

Oleh karena itu, kemampuan berbahasa sangat penting dimiliki oleh mediator. Pada data hasil penelitian di atas disebutkan bahwa salah satu aspek dalam masalah kegagalan mediator pada proses mediasi perkara adalah kurangnya kalimat-kalimat yang menggugah dan berpengaruh serta memberi daya dorong bagi para pihak untuk jernih melihat persoalan. Hal ini tentu berhubungan dengan kemampuan seorang mediator dalam berkomunikasi. Keterkaitan tersebut secara khusus mengarah pada pemilihan jenis tuturan yang digunakan selama proses mediasi.

\section{KESIMPULAN}

Erat kaitannya antara bahasa Indonesia dengan keadilan hukum. Oleh karena itu untuk meminimalisir tidak tercapainya keadilan diperlukannya pemakaian bahasa Indonesia yang baik dan benar oleh semua yang bersangkutan baik lembaga peradilan ,korban,penasihat dan yang memiliki pengaruh di dalamnya.

Di Indonesia, masih banyak sekali kasus kasus yang terjadi mengenai pemakaian bahasa Indonesia yang belum tepat dalam penyelesaian kasus, misalnya pada kata paten yang memiliki arti ganda atau gratifikasi yang mana memiliki arti uang yang diberikan dengan ketulusan atau uang yang diberikan untuk proses suap, tentu hal ini menghasilkan ketidakpastian hukum, sehingga dalam hal ini diperlukan Pemakaian bahasa Indonesia yang baik dan benar. 
Pemakaian bahasa Indonesia yang baik dan benar dalam kasus ini adalah pemakaian bahasa sebagai alat komunikasi dengan menggunakan kaidah penggunaan bahasa yang sesuai dengan aturan seperti kamus besar bahasa Indonesia (KBBI) baik berbenuk tertulis atau lisan yang mana dapat dikatakan baik dan benar apabila sesuai dengan kaidah ,tanda baca, tata bahasa, makna , ataupun bentuknya.

Di Indonesia sendiri perkembangan bahasa Indonesia memiliki sisi positif dan negatifnya masing masing, hal ini terlintas karena terdapat pengaruh perkembangan teknologi yang berada di dalamnya. Pengaruh positif dari perkembangan bahasa Indonesia diantaranya adalah bahasa Indonesia mulai dikenal oleh dunia internasional, meningkatkan pembenaran makna dan timbulnya kosa kata baru yang dapat mengartikan suatu hal baru, sehingga secara tidak langsung hal ini dapat memperkaya kosa kata bahasa Indonesia kita. Namun ,dampak negatif dari perkembangan bahasa Indonesia diantaranya adalah masyarakat Indonesia tidak menggunakan bahasa Indonesia yang baik dan benar ,hal ini dikarenakan muncul kosa kata asing atau bahasa gaul ,serta bercampurnya bahasa Indonesia dengan bahasa asing yang lebih dominan yaitu bahasa Inggris.

Dari penelitian ini disimpulkan bahwa menurut responden bahasa indonesia yang digunakan dalam dunia hukum belum sesuai dengan kaidah yang tepat sehingga hal ini menimbulkan ketidakpahaman bagi orang orang awam dan menyebabkan mereka merasa tidak mengerti dengan hasil penyelesaian kasus tersebut. Maka diharapkan dengan dilakukan dan dibuatnya karya tulis ilmiah ini, tidak akan ada yang merasa menjadi korban dan memberatkan beberapa pihak dengan ketidaktahuan mereka terhadap bahasa Indonesia ataupun bahasa hukum yang disampaikan oleh lembaga peradilan.

\section{DAFTAR PUSTAKA}

Alwi, H., Dardjowidjojo, S., Lapoliwa, H., \& Moeliono, A. M. (2003). Tata bahasa baku bahasa Indonesia.

Anisa, L. N. (2015). Implementasi Prinsip Neutrality Dalam Proses Mediasi. Al-Mabsut: Jurnal Studi Islam Dan Sosial, 9(1), 179-197.

Endang, E., \& Fitriani, Y. (2019). Analisis Kesalahan Penggunaan Bahasa Indonesia Dalam Laporan Hasil Observasi Pada Siswa SMA. Jurnal Pembahsi 
(Pembelajaran Bahasa Dan

Sastra Indonesia), 9(1), 24-31.

Kusno, G. (2011). Sepuluh Bahasa

Terbanyak Dipakai di Dunia.

Accessed on January, 26, 2016.

Muaffaq, N. A. (2012). Fonologi Bahasa

Indonesia. Alaudin University Press.

Mustakim, M. (1996). Tanya jawab Ejaan Bahasa Indonesia untuk Umum. Gramedia. 